\title{
Moral and Legal Liability in Medical Malpractice (A contemporary View from the Forensic Medical point of View)
}

\author{
Emad Fekry Mohamed Aly ${ }^{1}$
}

\begin{tabular}{|c|c|}
\hline & ABSTRACT \\
\hline $\begin{array}{l}\text { KEYWORDS } \\
\text { Medicolegal responsibility, } \\
\text { Medical malpractice, } \\
\text { Compensation. }\end{array}$ & $\begin{array}{l}\text { In recent years, the steady increase in civil and criminal cases resulting from } \\
\text { medical malpractice, not only in our country, but even in developed countries, } \\
\text { attracted my attention. It increased to the extent that it has become discussed, almost } \\
\text { daily, in the media, conferences and scientific seminars, locally and globally, in } \\
\text { addition to the corridors of the courts. Medical responsibility acquires special } \\
\text { importance because the medical profession is considered one of the noblest human } \\
\text { professions, and the doctor who promotes it needs a great deal of knowledge, } \\
\text { freedom, trust and reassurance. On the other hand, the patient's life or physical } \\
\text { integrity is considered one of the most important values that society seeks to protect } \\
\text { and are considered matters of public order. We can point out that, recent scientific } \\
\text { discoveries, the tremendous development in medical science, its association with the } \\
\text { medical mistakes and the occurrence of harm to the patient as a result of these } \\
\text { mistakes, made the person threatened in his health. From this point of view, the } \\
\text { countries had to modify laws and legislation to preserve the patient's safety and } \\
\text { protect him from violations of health service providers, and their accountability for } \\
\text { their medical mistakes committed against the patient. Some countries have formed } \\
\text { special courts for medical malpractice cases. Some countries have also moved to the } \\
\text { medical insurance system against medical malpractice. }\end{array}$ \\
\hline
\end{tabular}

ونـشير إلــى أن الاكتــشافات العلمبـــة الحديثـة

و التطور الهائل في العلوم الطبية و اقتر انها بوقوع مقدمي

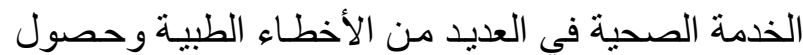

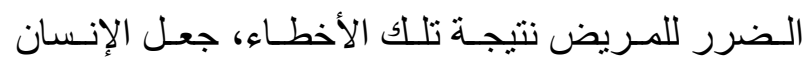

مهددآ في صـحته، مسن هنـا كـان لابـد للدول مسن وضـع

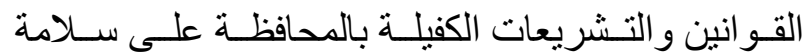

المريض وحمايته من تجاوزات مقدمي الخدمـة الصحية،

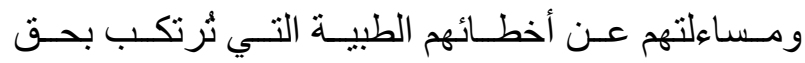

المـريض، وقامـت بعض الـدول بتشكيل محساكم خاصــة

بقضـايا الأخطـاء الطبيـة للنظـر في قضـايا المسؤولية

الطبية بمعزل عن القضايا الأخرى، كمـا اتجهـ الدول

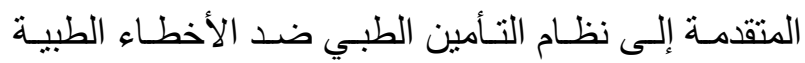

\footnotetext{
(1) Forensic Medicine and Clinical Toxicology Department, Mansoura University, Egypt.
}

$$
\begin{aligned}
& \text { جذب انتبـاهي في السنوات الأخيرة، تلك الزيـادة }
\end{aligned}
$$

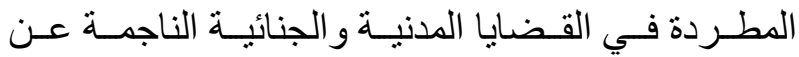

$$
\begin{aligned}
& \text { الأخطـاء الطبيـة، لبيس في بلادنـا فحسب، بـل حتى في في } \\
& \text { البلدان المتقدمة، لدرجة أنها أصبحت مادة شبه يومبة في } \\
& \text { وسـائل الإعـلام و المـؤتمر ات و النـدو ات العلمبــة محليـاً }
\end{aligned}
$$

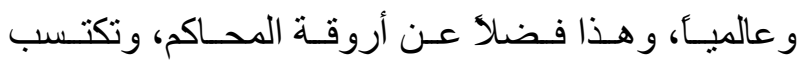

$$
\begin{aligned}
& \text { المسؤولية الطبيـة أهميـة خاصسة لأن مهنـة الطب تُعَد من ونس }
\end{aligned}
$$

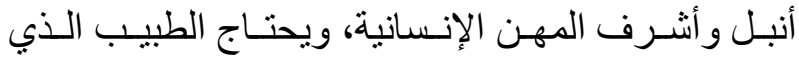

$$
\begin{aligned}
& \text { يـنهض بـهـا إلـى قـدر كبيـر مـن العلـم و الحريـة و الثقـة }
\end{aligned}
$$

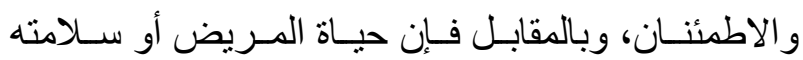

$$
\begin{aligned}
& \text { الجسدية، ثُعد من أغلى القيم التي يحرص المجتمع على ولى } \\
& \text { حمايتها والتي تُعتبر من الأمور المتعلقة بالنظام العام. }
\end{aligned}
$$


وقد أنششأت نقابـات المهـن الطبيـة المصرية طبقـ

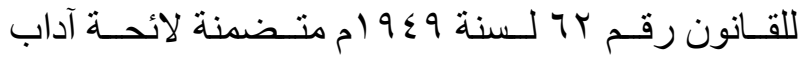
و ميثاق شرف مهنة الطب و التي تم تعديلها بقر ار معالي

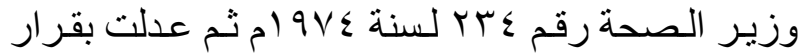

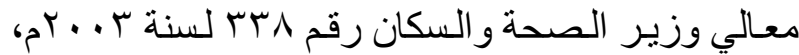

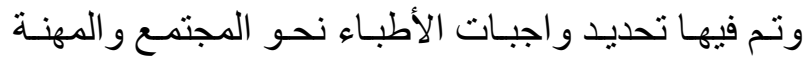

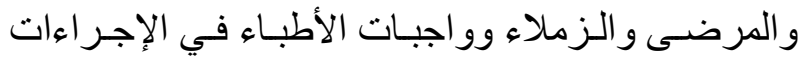

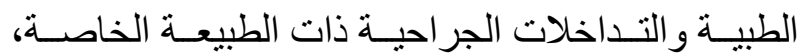

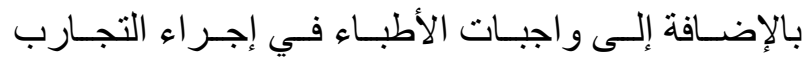

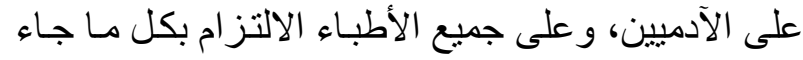

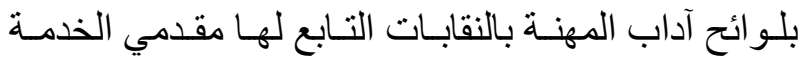

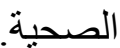

r - المسؤولية القانونيـة، تقسم إلى مسؤولية مدنيـة أو

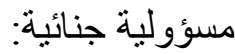

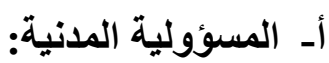

يُقصد بها، من الناحيـة الطبية، الأعمـال الإيجابيـة

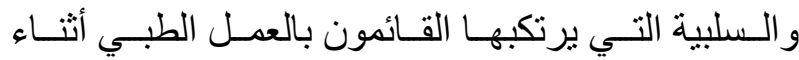
الممارسـة الطبيـة التي تستوجب المساءلة القانونيـة عندـ حدوث ضرر/وفاة المريض، التي تتمثل في جبر الضرر

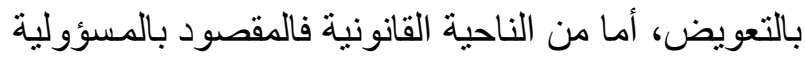

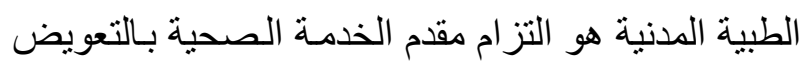
عن الضرر الذي سببيه للمريض نتيجـة مخالفتهـه لبنـود

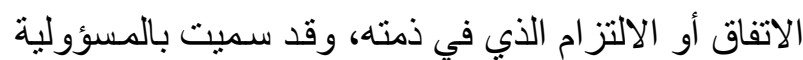

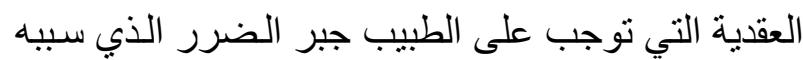
للمريض نتيجة خطئه الطبي بالتعويض.

ونشثير إلى أن الأخطـاء الطبيـة التي ثرتب لقيـام

المسؤولية الطبية المدنية تتعلق بالنواحي العملية و العلميـة الإنية

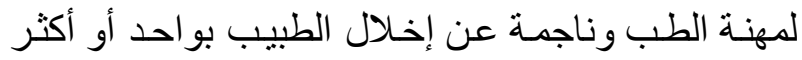
من المبادئ المتفق عليها في عرف المهنة بصورة تؤدي الطي إلى وقوع الضرر على المريض أو التسبب في ذللك،

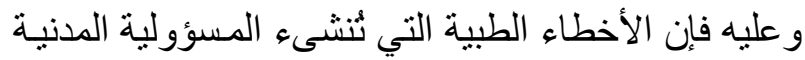

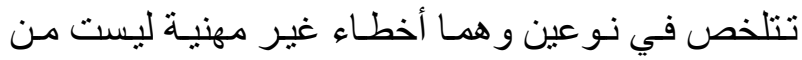
جنس العمل الطبي وأخطاء مهنية من جنس العمل الطبي

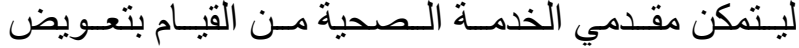

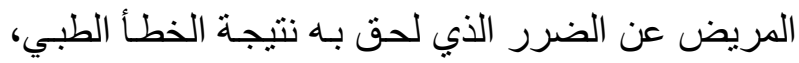

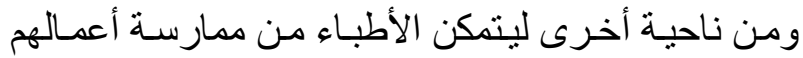

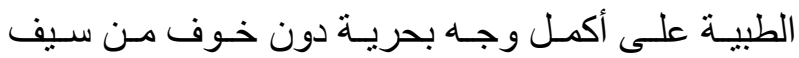

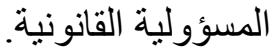

المسؤولية الطبية

المسؤولية الطبية في معناها العام عند فقهاء القانون

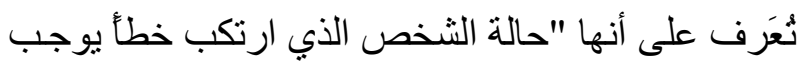

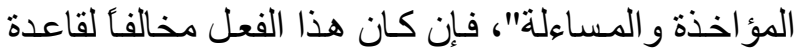
أخلاقية، وصفت مسؤولية مرتكب الفعل بأنها مسؤولية

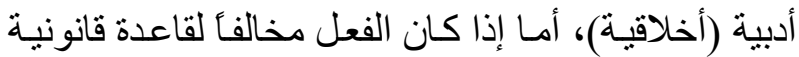

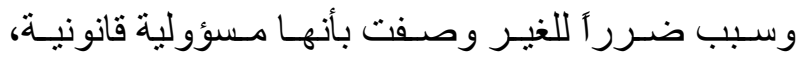

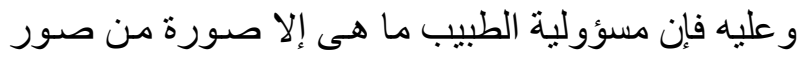

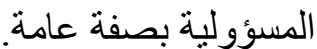

\section{ومسؤولية الطبيب في الأخطاء الطبية تقسم إلى مسؤولية أخلاقية ومسؤولية قانونية: 1 المسؤولية الأخلاقية (الأدبية):} هـى في الأسـاس مسؤولية سـوكية قبل أن تكون مهنيـة فهى تتعلـق بسلوك الطبيـب تجـاه المهنـة وتجـاه

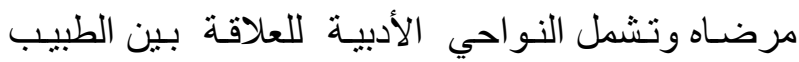
و المريض، وتتعلق هذه المسؤولية بجملة من المبادئ الأخلاقية المطلوبة من جميع الأفراد، غير هذولة أنها في علاقة هن

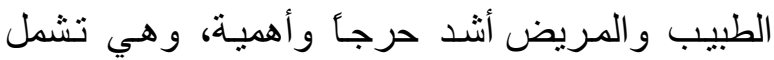

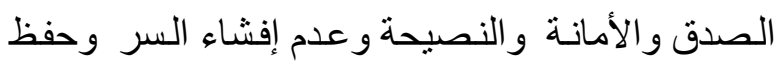
العورة و الوفاء بالعقد وغير هـا من السلوكيات، وتنشأ

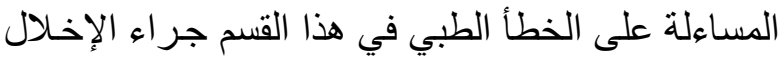

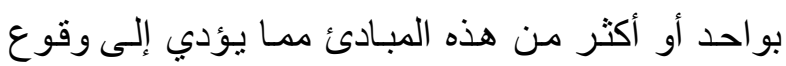

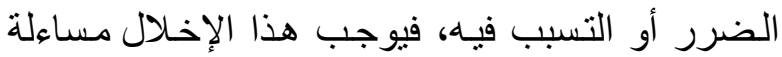

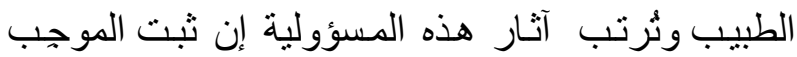

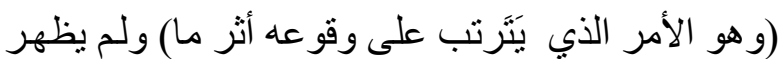
له عُّر مبيح. 
منحه ترخيص بمز اولة المهنـة الصحية بالمخالفة

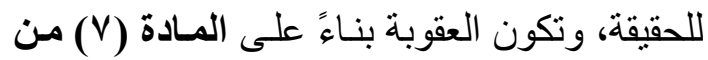

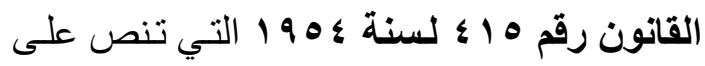
أنه " كل قيد فى سجل الأطباء بالوز ارة تم بطريق أنق

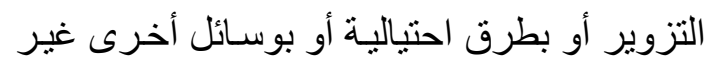

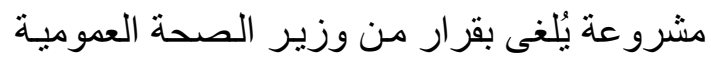

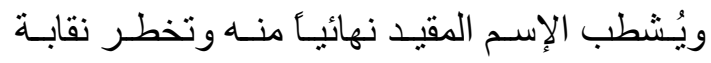

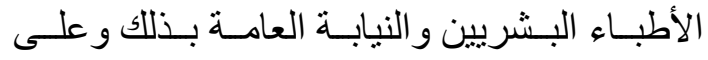
النقابـة إخطار وزارة الصحة العموميـة بكل قرار يُصدره مجلسها أو هيأتها التأديبية بوقف الطبه الطبيب عن مز اولة المهنة أو شطب اسمه".

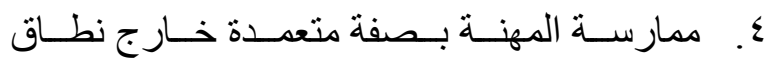
التخصص أو الامتياز ات السريرية التي يتمتع بها الطبيب بموجب التـرخيص الممنوح لـه، ويُسأل لئل

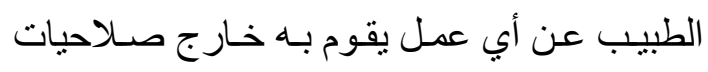
الرخصة الممنوحة له. •. القيام بإجر اء طبي أو تداخل جر احي بمكان غير

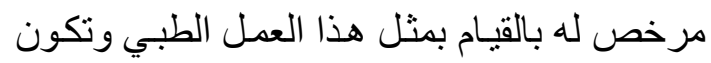
العقوبة بناءً على قانون تتظيم المنشآت الطبية رقم

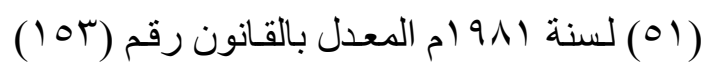

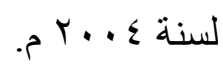
7. انحر اف الطبيب غير المبرر عن الأصسول العلميـة

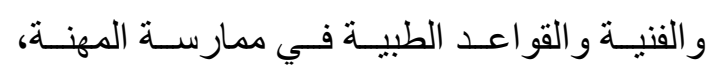
وتكون العقوبـة المقررة على الطبيب هي الحبس

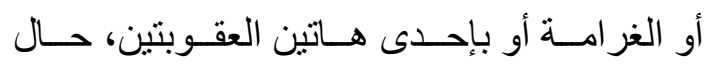

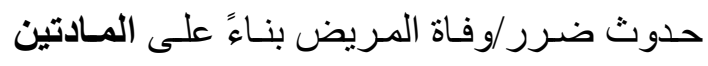

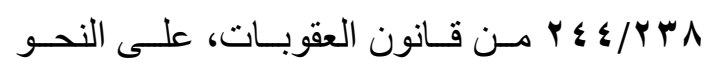
الموضح تفصيلا أدناه. V. . استعمال الطبيب لوسـائل تشخيص أو علاج غير

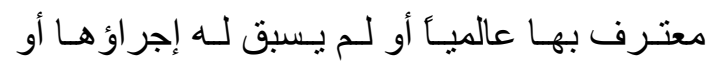

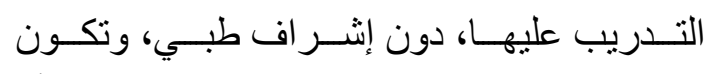

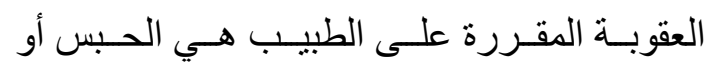
الغر امة أو بإحدي هاتين العقوبتين وذلك بنـاءً على الطى
وتشمل ثنلاثـة محساور هـى أخطـاء التشخيص، وأخطساء

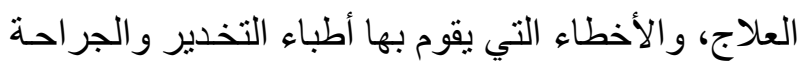

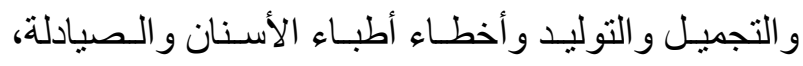

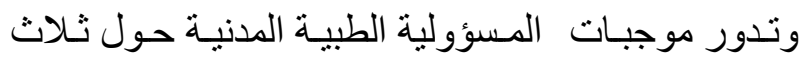

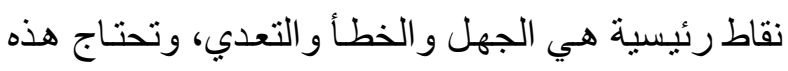
الموجبات إلى الكثير من الضبط و التفصيل.

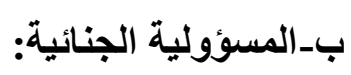
المسؤولية الطبيـة الجنائيـة هـى المسؤولية التـي تقوم عند مخالفة مقدم الخدمة الصحية لقاعدة قانونية آمرة

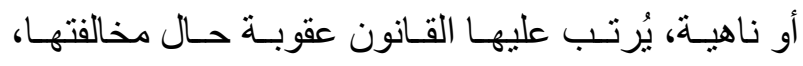

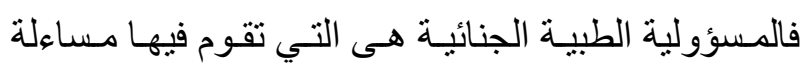

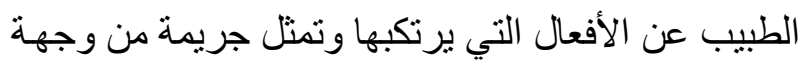

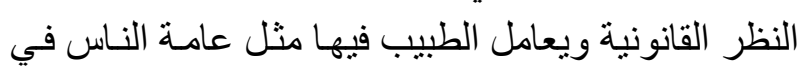

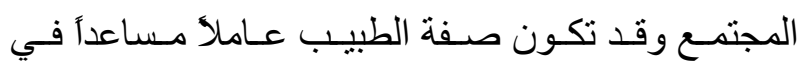

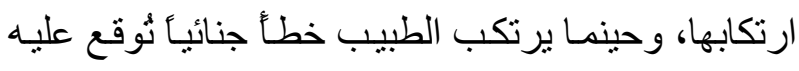

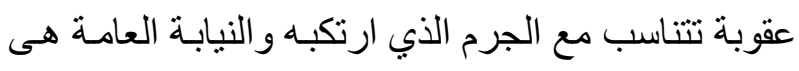

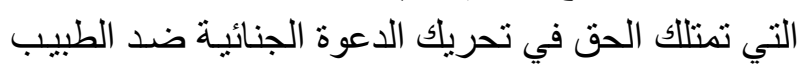

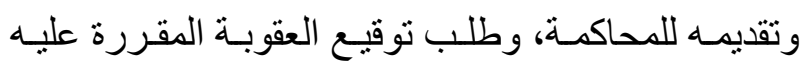
حسب القانون، ومن أمثلتها ما يلي: وطيح

ا ـ قيام مقدم الخدمة الصحية بمخالفة أي من القوانين

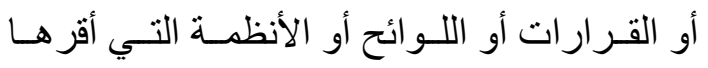

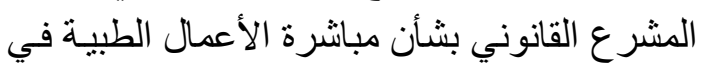

$$
\text { مصر. }
$$

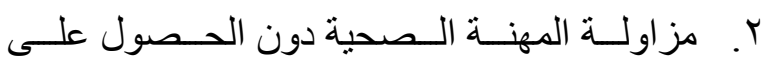

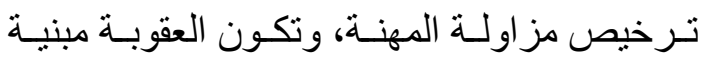

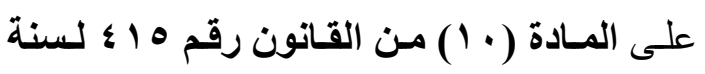

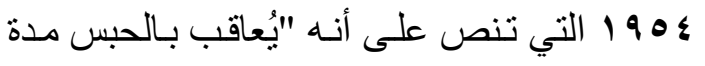

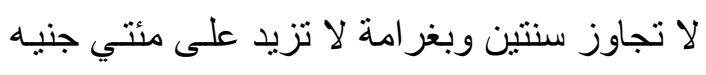

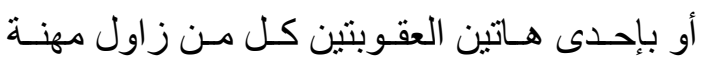

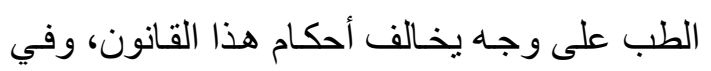
حالة العود يحكم بالعقوبتين معاك".

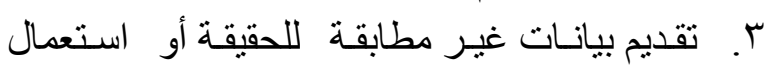
الطبيب طرقأ غير مشروعة كان من نتيجتها 
أـ يجب الحصول على المو افقة الخطية المستنيرة من المريض أو من بمثله قانونأ في حال عدم الأمة الأهلية.

ب- يجب الحصول على مو افقة المنشأة الصحية. تـ التصوير يتم لأغر اض علمية معتمدة.

ثـ ألا يخالف الآداب العامة وأخلاقيات المهنة. في هذه الحالة يقع الطبيب تحت طائلة المـادة

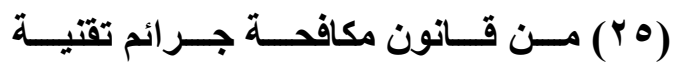

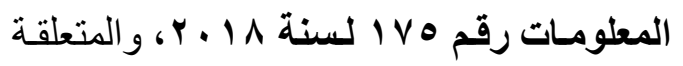

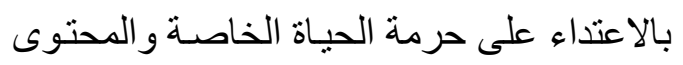
المعلوماتي غير المشروع التي تنص على أنسه

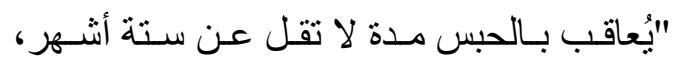

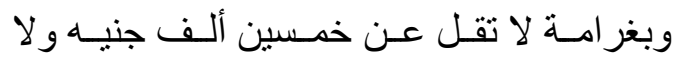

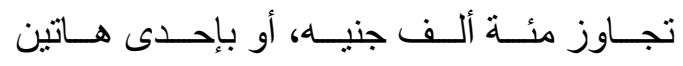

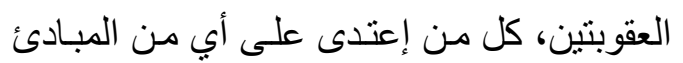

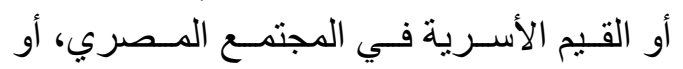

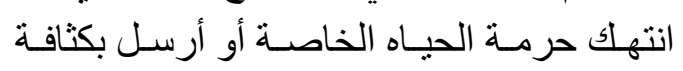

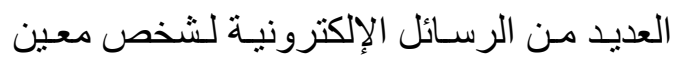

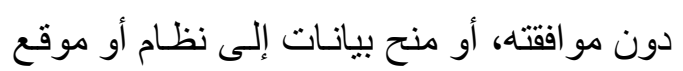

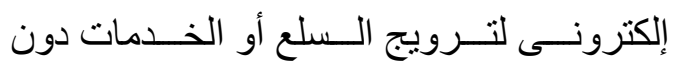

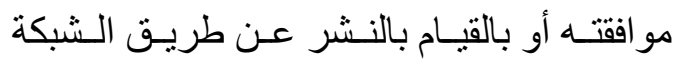

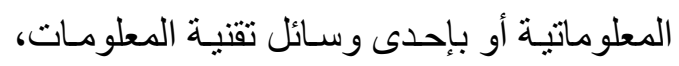

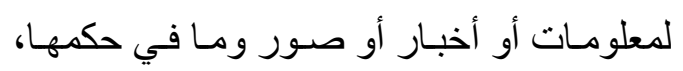
تنتهك خصوصية أي شخص دون رضاه أو أو سواء

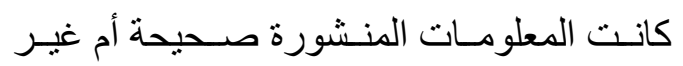

$$
\text { صحيحة". }
$$

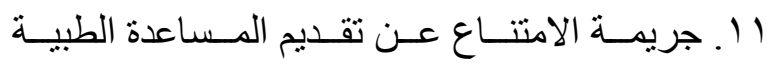

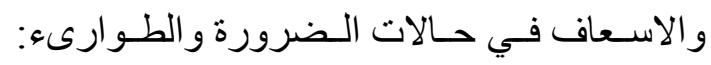

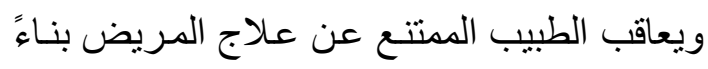

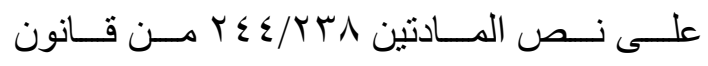

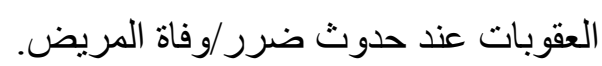

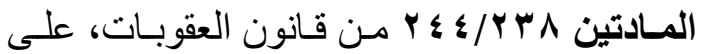
النحو الموضح تفصيلا أدناه. ^. جريمـة تزويـر وكتابـة التقارير /الشهادات الطبيـة

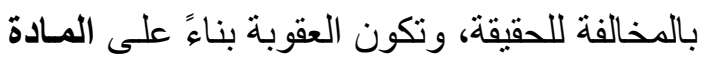

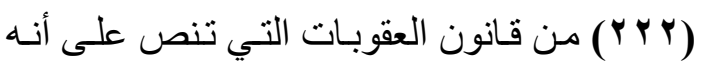

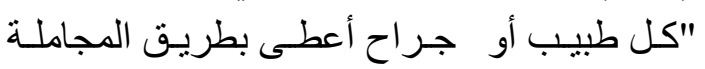

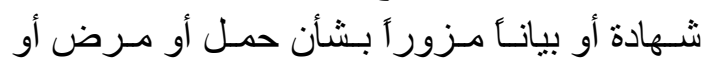

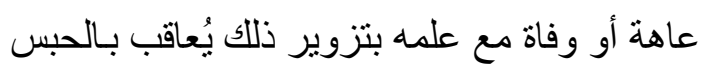

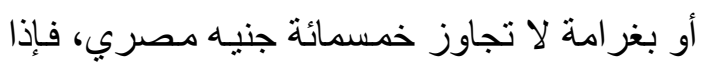
طلب لنفسه أو لغيره أو قيل أو أخذ و عداً أو عطية

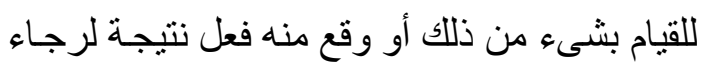

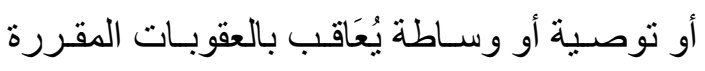

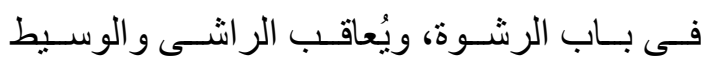

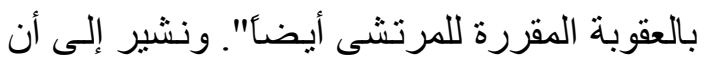

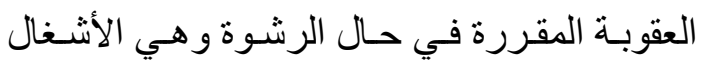

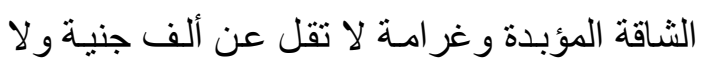

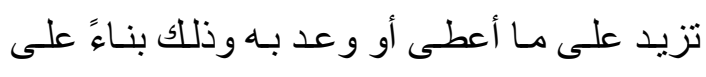

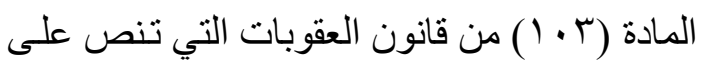

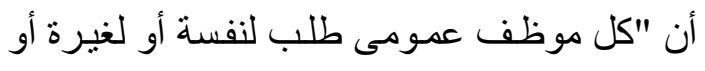

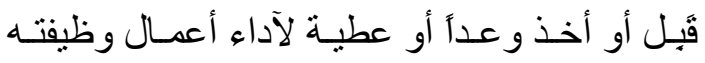

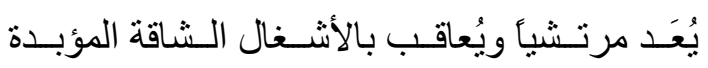

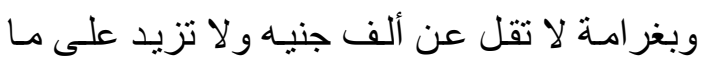
أعطى أو و عد به".

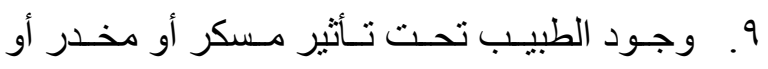

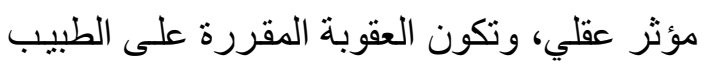

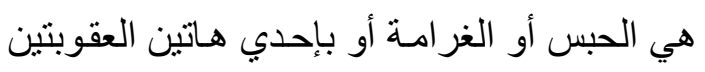

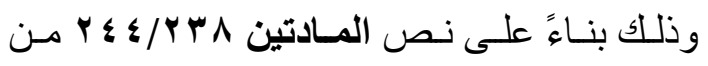
قانون العقوبات. • أ. نشر صور المريض أو صور العمليات الجر احيـة

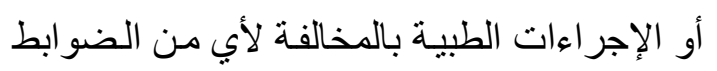
الآتية: 
على أسـاس أن الضرر قد أصساب شخطأ بحد ذاته.

r- تهدف المسؤولية الجنائية إلى إيقاع أثد العقاب بالجاني لردع كل من تسول له نفسه القيام بذللك

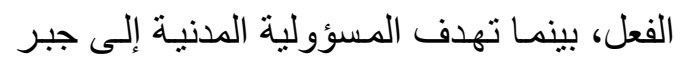

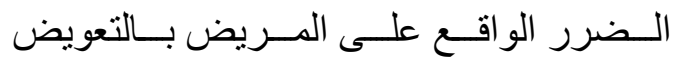
المادي.

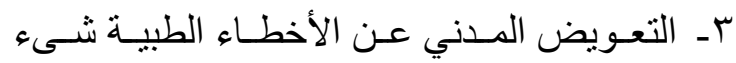

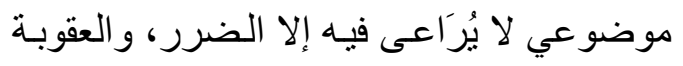

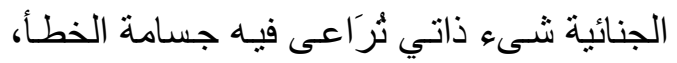
و هذا هو مقتضى فصل التعويض المسادي عن العقوبة الجنائية. ــ الذي بطالب بالعقوبة في المسؤولية الجنائية هو

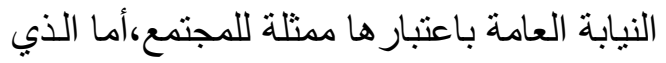

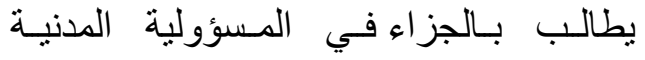
فالمضرور نفسه لأن الجزاء حقه هو.

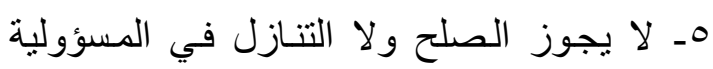
الجنائية لأن الحق فيها عام للهجتمع ويجوز الصلح و التنازل في المسؤولية المدنية لأن الحق ولقان

$$
\text { فيها خاص للفرد. }
$$

7ـ لما كانت العقوبة في المسؤولية الطبية الجنائية

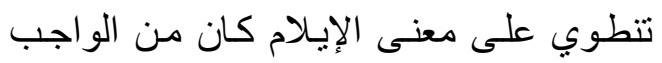

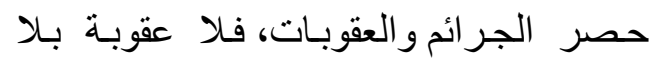

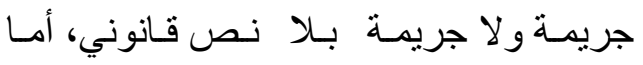

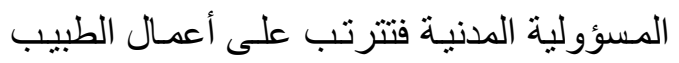

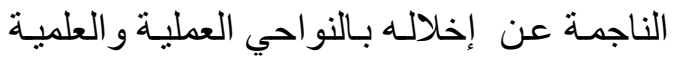

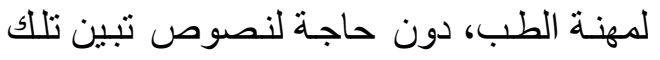
الأعمال.

V- توفر النية شرط في المسؤولية الجنائية التي لا بد أن يكون لها مظهر خـارجي يصل إلى حد

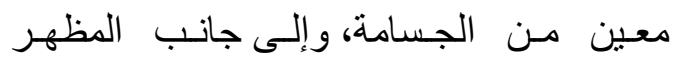
الخارجي يغلب أن تكون الجريمة الجنائية عملا الجالِ قد ألحق الضرر بالمجتمع. r ا . جريمة إفثاء السر المهني: العقوبـة المقررة على من ارتكب جريمة إفشاء السر المهني، في المـادة الماءة

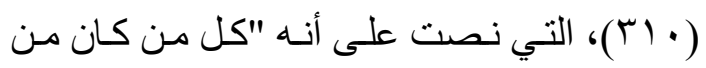

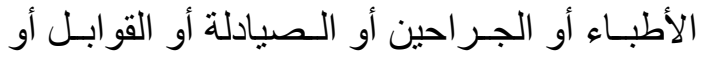

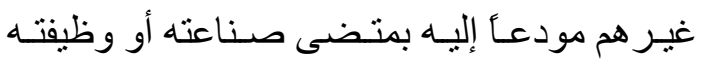

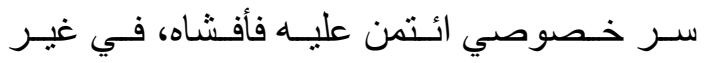

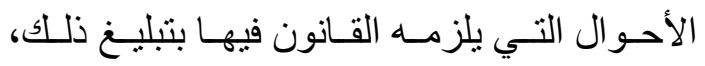

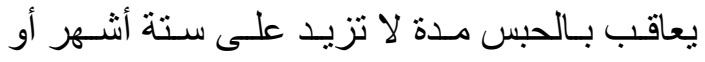
بغر امة مالية لاتتجاوز خمسمائة جنيـة، و لا تسري

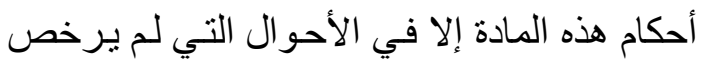
فيها قانون بإفشاء أمور معينة". rا . جريمة إجر اء الإجهاض الجنائي: ورد في المـادة

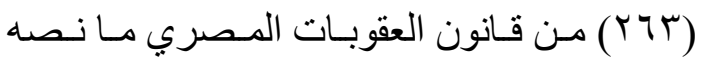

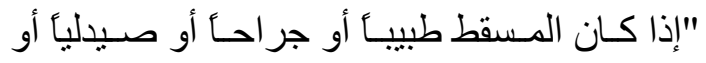
قابلة يحكم عليه بالسجن المشدد" الدانط

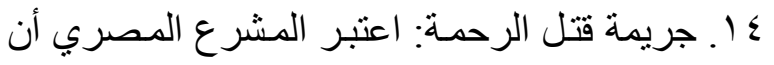

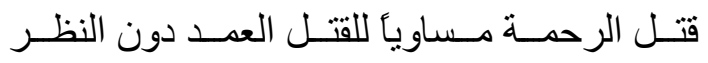
للأسباب والدو افع، ويُسأل الطبيب جنائياً في حال إقدامه على إحداث موت الثفقة. 0 ا ـ جريمـة إسـاءة اسـتخدام وتســيل تعـاطي وكتابـة العقاقير التي تحتوي على مواد مخدرة، ويعاقب

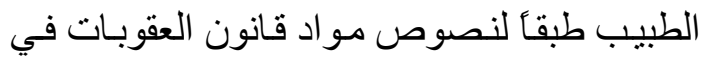

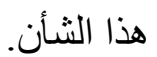
17 ا ـ جريمة نقل وزر اعة الأعضاء والأنسجة البشرية

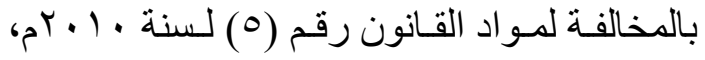

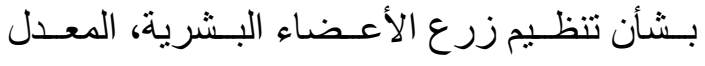
نصوص بعض مواده، بالقانون رقم (r \& ( ) لسنة . IV و فيها بلي الفروق بين المسؤوليتين الطبيتين الجنائية ا ـ تقوم المسؤولية الجنائيـة على أن هناك ضـرراً

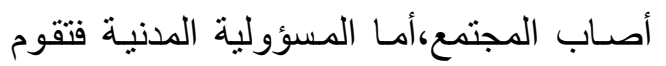


الأسـاليب العلاجيـة بالإضـافة إلى ضــف مستو اه الفني

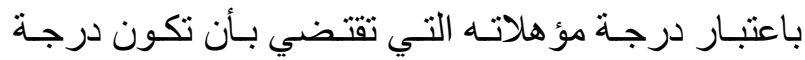

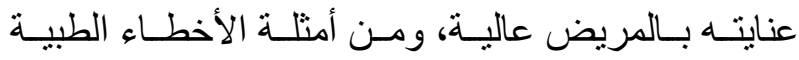
المبنية على الإهمال، مايلي:

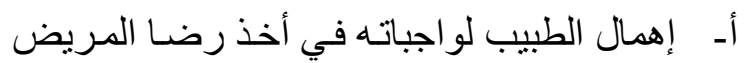

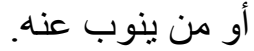

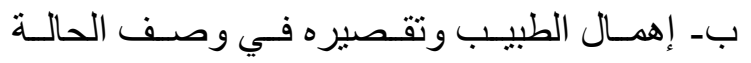
للمريض أو ذويه.

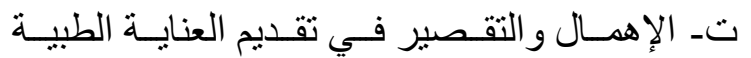

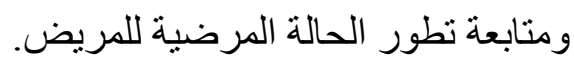
ثـ عدم إسعاف من بحاجة إلى إسعافه.

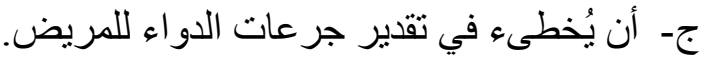

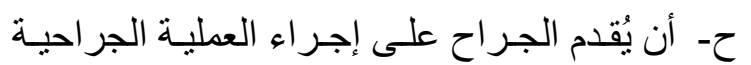
وهو في حالة سكر.

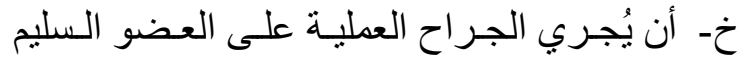
بدلا من العضو المصاب.

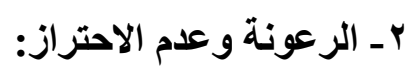

يقــد بالرعونــة سـوء التقــير وعـدم الالتـزام

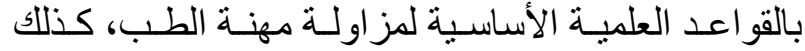

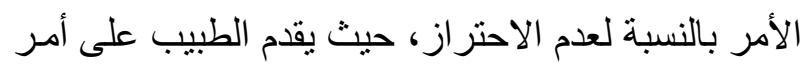

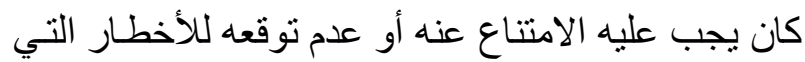
قد تترتب على عملـه الطبي بالإضـافة إلى عدم اتخـاذه الإجر اءات الوقائية المناسبة لدرء هذه الأخطار.

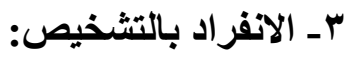

انفر اد الطبيب بالتشخيص أمر غير مقبول خاصـة

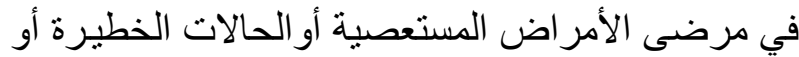

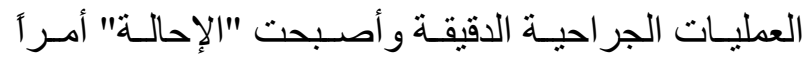

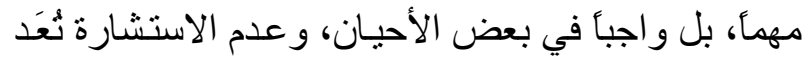

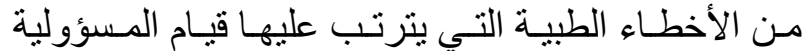
الطبية حال حدوث ضرر/وفاة للمريض، وفي هذا السياق

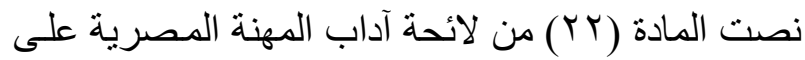

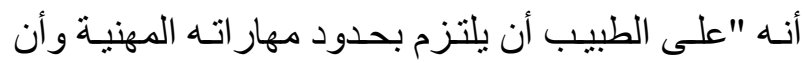

\section{• أركان المسؤولية الطبية من الناحية القانونية}

حتى تنهض المسؤولية الطبيـة، ويصبح الطبيب

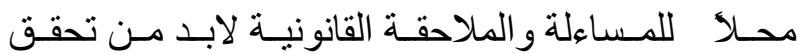
العناصر الثلاثة التي تشكل، من الناحيـة القانونيـة، أركان لاندان المسؤولية الطبية، التي تشمل ما يلي:

الركن الأول: حدوث الخطأ الطبي من قِبِل الطبيب

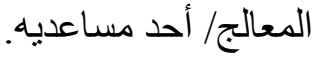

الركن الثاني: حصول ضرر للمريض نتيجة هذا الخطأ الطبي المرتكب. ئر

الركن الثالث: وجود علاقة سببية مباثرة تربط

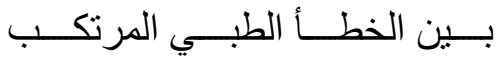
والضرر الحاصل للمريض.

\section{الركن الأول: الخطأ الطبي}

الخطأ الطبي يُعَرف بأنسه "كل مخالفة أو خروج

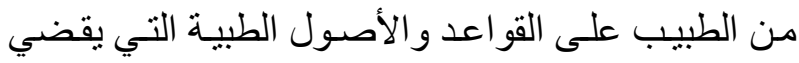

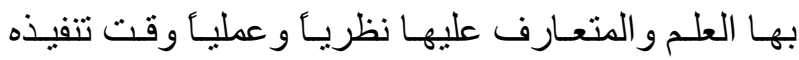
للعمل الطبي أو إخلاله بو اجبات الحيطة و الحذر و اليقظة التي يفرضها القانون وو اجبات المهنة على الطبيب، متى التى

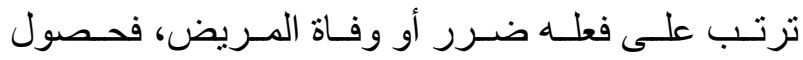

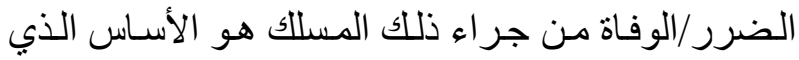
يرتب نشوء المسؤولية الطبية. o أسباب الأخطاء الطبية:

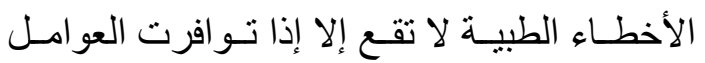

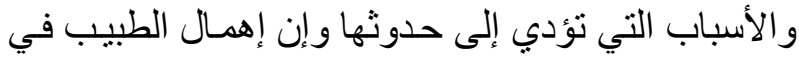
عمله ور عونته و إخلاله بالتز امه المهني يؤدي إلى حدوث الهاب الهاب

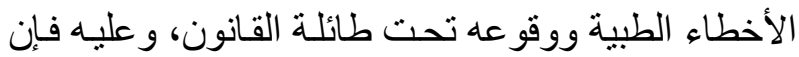
من أهم أسباب الأخطاء الطبية ما يلي:

ا ـ الإهمال وعدم بذل العناية:

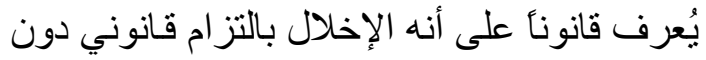

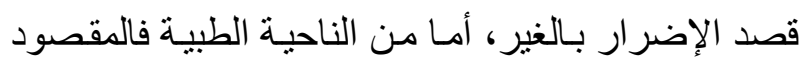

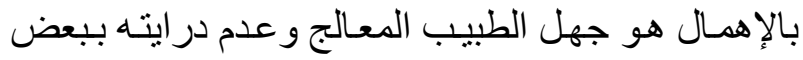


خطير أو معدي، ممـا يسىء إلى سمعة الشخص ويلحق الأذى بمركزه المالي والإجتمـاعي، و أيضأ من أمثلـة هذا

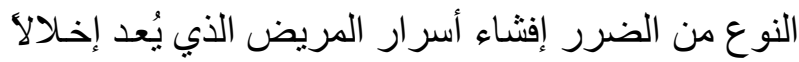
من الطبيب بالتزامه بالو اجبات الطبية تجاه المريض.

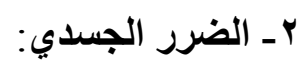

يُقصد بـه الضرر الذي يصيب المريض في جسمه، وينتهك حق الإنسان في سلامة الجسم أو الحق في الحياة، وقد يكون الضرر الجسدي الذي يلحق بـالمريض نتيجة الإنس الأخطاء الطبية أحد نوعين، هما:

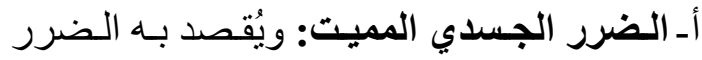

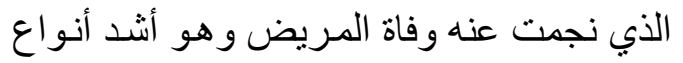

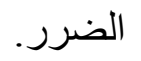

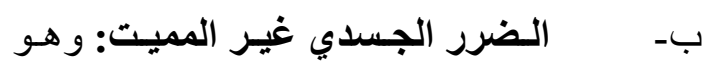
الضرر الذي يؤدي إلى تعطيل جزئي أو كلي

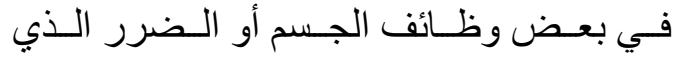

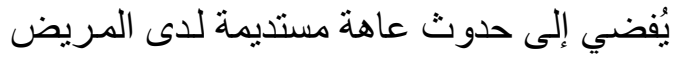
نتيجة الخطأ الطبي المرتكب.

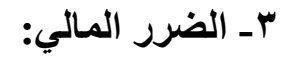

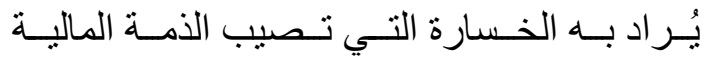

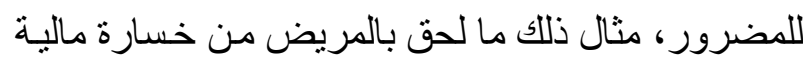

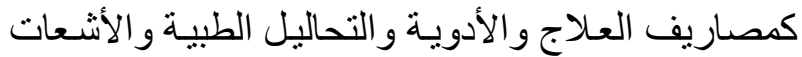
و الإقامة بالمستشفي ونفقات إصلاح و وعلاج الخطأ الطبي

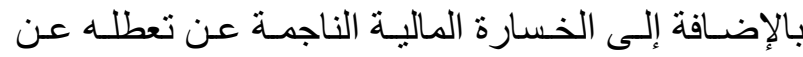

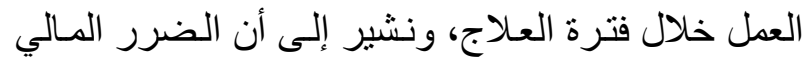

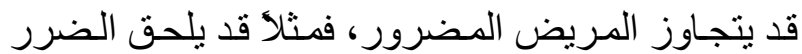

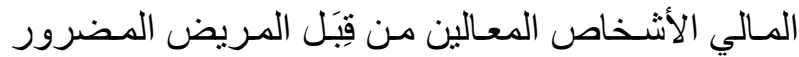

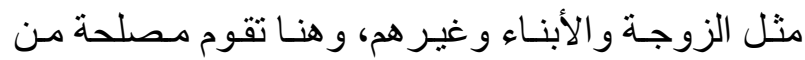

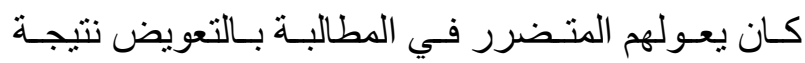

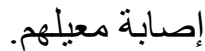

الركن الثالث: علاقة السبيية بين الخطأ الطبى والضرر تُعد علاقـة السببية أسـاس قيـام المسؤولية المدنيـة فلا يمكن تصور ضرر نـاتج عن خطأ مـا لم تكن هنـاك فولك
يستعين بخبرة من هم أكفأ منـه من الأطباء في منـاظرة وعلاج مريضه عند اللزوم".

ع ـ عـدم مراعـاة القــوانين واللـوائح المنظمـة للعمـل الطبي:

الترخيص القانوني هو الأسـاس الذي تستند إليها

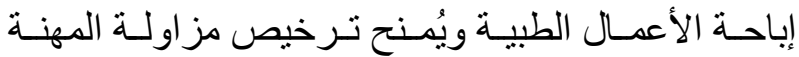

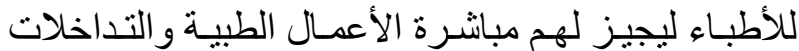

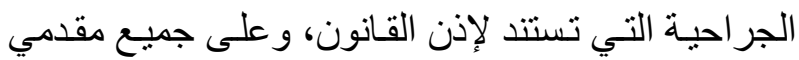

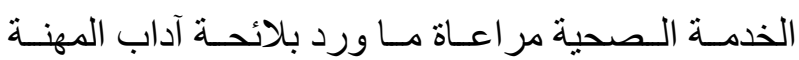

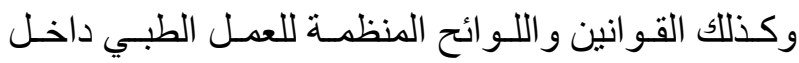

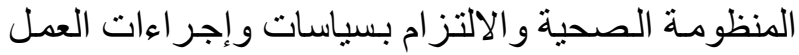
و آلية تنظيم وتسيير العمل داخل المنشآت الصحية.

$$
\text { الركن الثانى: الضرر في المجال الطبي }
$$

الضرر في المجال الطبي يُعَرف بأنه حالة نتجبت

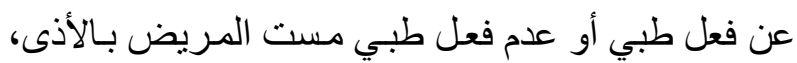
وقد نتج عن ذلك تأثنير سلبي انعكس على فعل المريض سو اءً

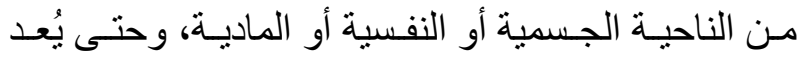

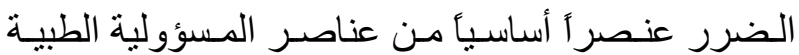

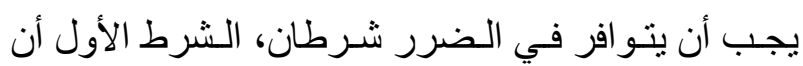

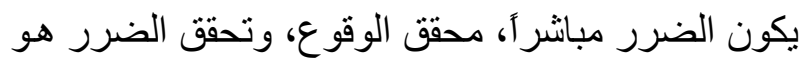

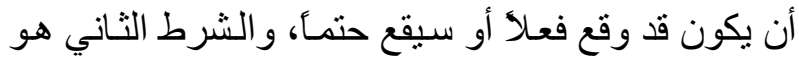
أن يمس الضرر حقاً ثابتأ مشرو عأ بنظر القانون، مثل فئل سلامة الجسم أو حق الحياة. م يُقسم الضرر الذي قد يلحق بـالمريض، نتيجة

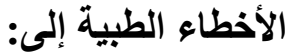

$$
\text { 1 - الضرر المعنوي: }
$$

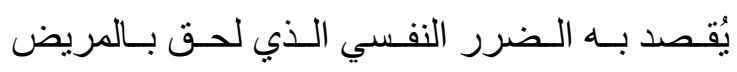

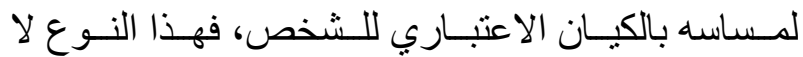

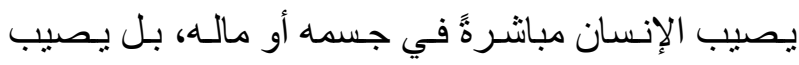

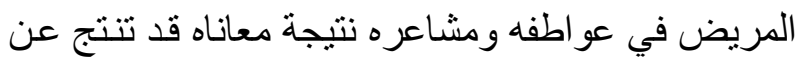
آلام بدنية من جانب أو نفسية من جانب آخر ، مثنال ذلك فئك

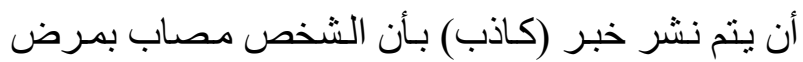


العلميــة الحاصـل عليهــا، فمسؤولية الطبيــبـ

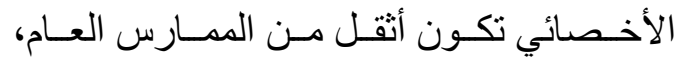

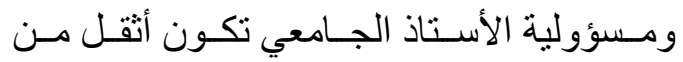
الاثثين، ونشير إلى أنه لا يتوقع من الطبيب الن أن

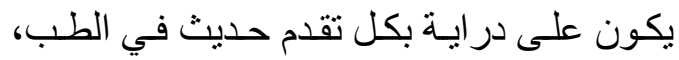
ولكن للمريض الحق في الحصول على عنى بـايـة

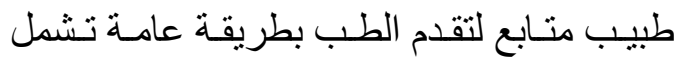
التطور ات الرئيسية.

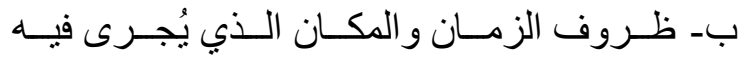

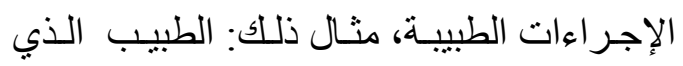
يعمل في الريف أو في منـاطق نائية ولا ينوفر لإنه

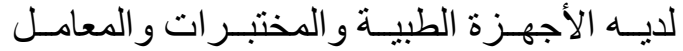

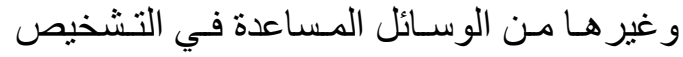

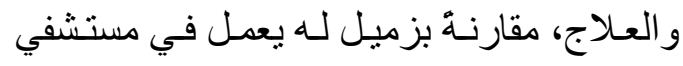
جامعي أو في مستشفي عسكري أو غير هـا من

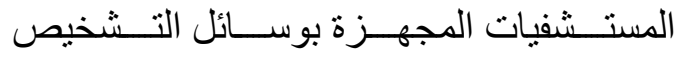

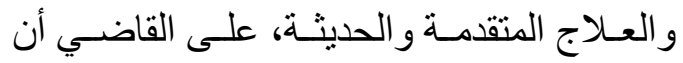

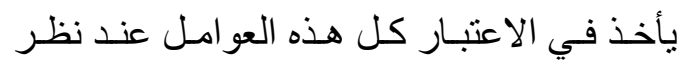

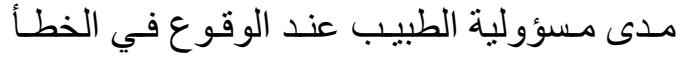
الطبي. تـ خطورة الحالـة ومـا تستلزمه مـن اسـعافات في

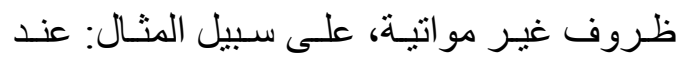

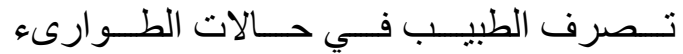
و الاسعاف، وغير ها من حالات الضرورة، فإن

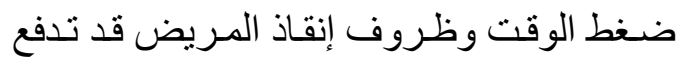

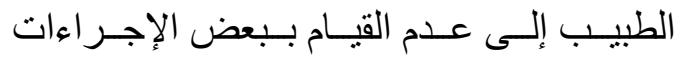

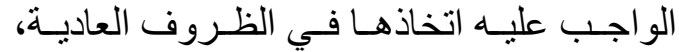

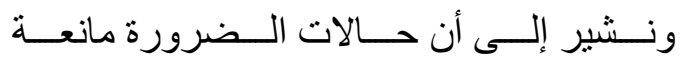

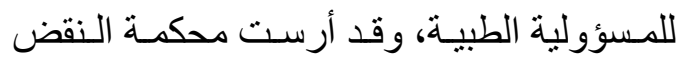

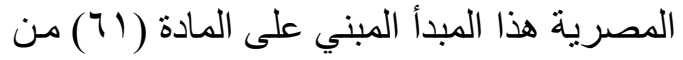

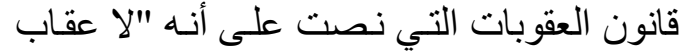

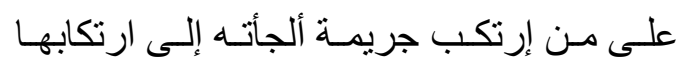
ضـرورة وقايـة نفسه أو غيره مـن خطر جسيم إنها

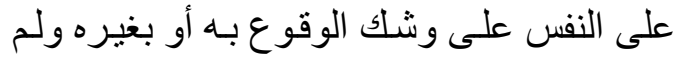

علاقـة سببية تجعل الخطـأ علـة الضرر وسبب وقوعـه، فمناط المسؤولية وجو هر ها علاقة السببية، ويُر اد بالعلاقة ولئة

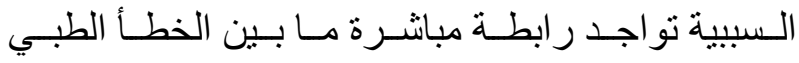

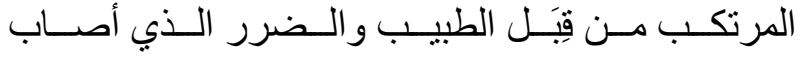

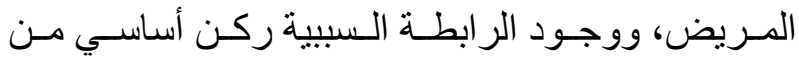
أركان قيام المسؤولية الطبية، إذ لا يكفي لقيام المسؤولية

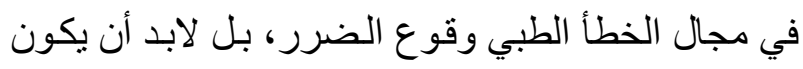

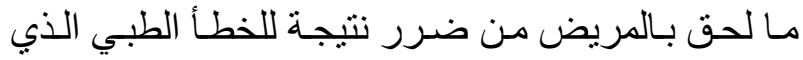

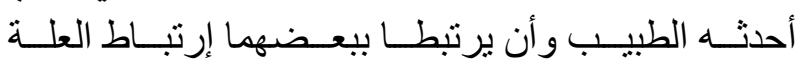
بالمعلول و السبب بالمسبب بحيث لا يمكن تصور حصول الضرر للمريض لو لم يقع الخطأ من الطبيب.

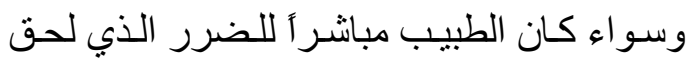

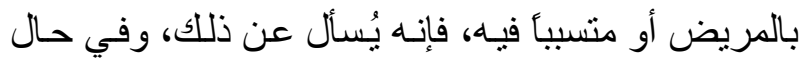
تعدد الأطباء أو اشتر الك الطبيب مـع بعض فإنه بـ مساعديه في

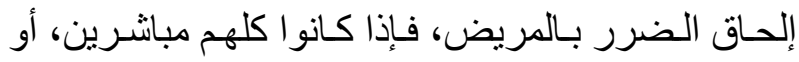

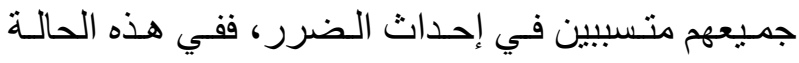

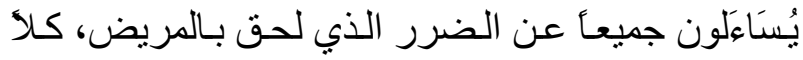
بمقدار مساهمة خطئه في تحقيق النتيجة، و إثبات أو نفي

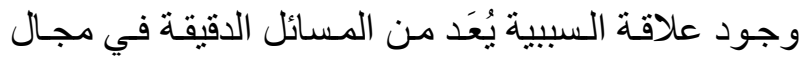

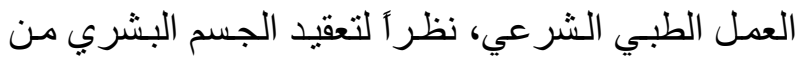

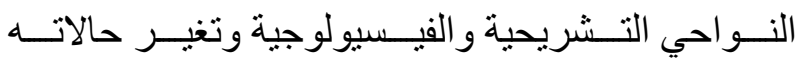
المرضية، حيث قد تتعدد وتتداخل أسباب حدوث الضرو وقد ثُنسب تللك الأسـباب إلى أثـخاص متعـددين أو قد وند

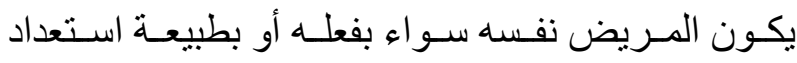

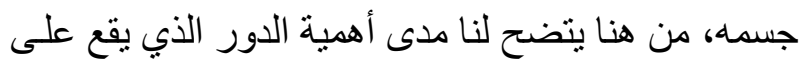

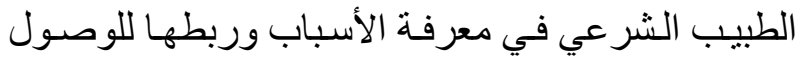
للحقيقة.

\section{معيار الخطأ الطبي}

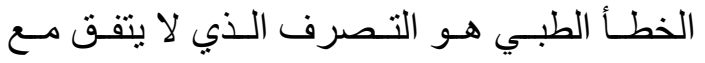

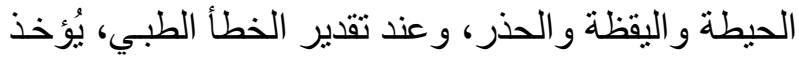
في الاعتبار ما يلي:

أــ المستوى المهني للطبيـب المشكو في حقـه مـن

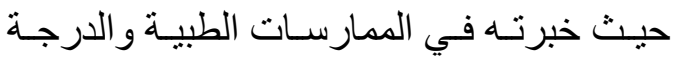


ونظر آلعدم وجود "قانون للمسؤولية الطبية" في

مصر ، فإن الطبيب يُعَاقب، في الأخطاء الطبية المهنية،

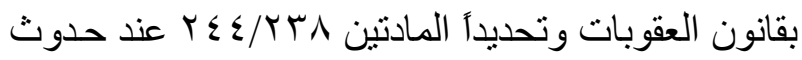

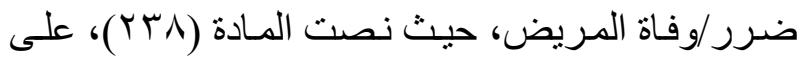

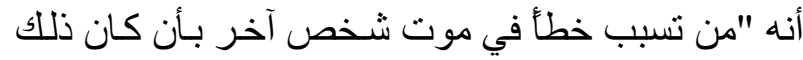

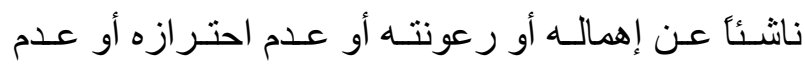

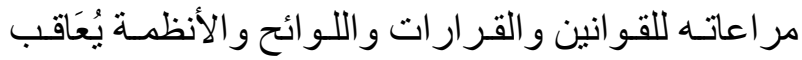
بـالحبس مدة لا تقل عن سـتة أثـهر وبغر امسة لا تجـاوز

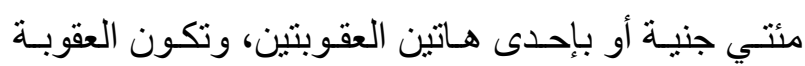

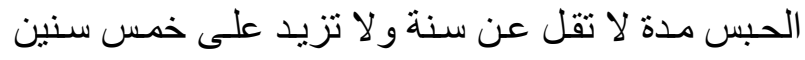

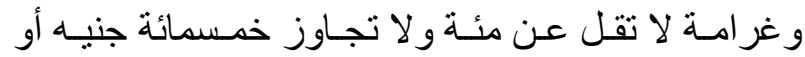
بإحدى هـاتين العقوبتين إذا وقعت الجريمـة نتيجة إخـالال

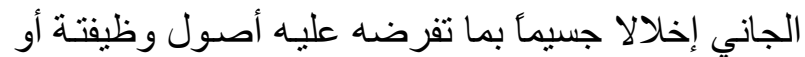

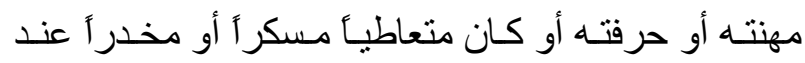

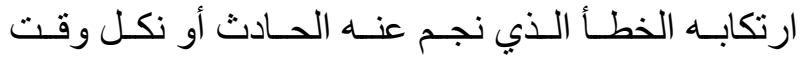

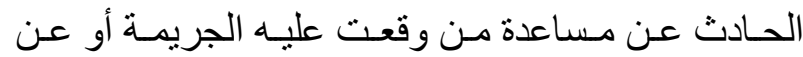

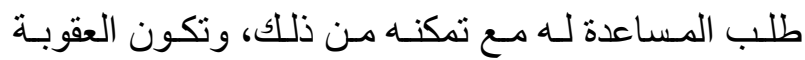
الحبس مدة لا تقل عن سنة ولا تزيد علي سبع سنين إذا لـا

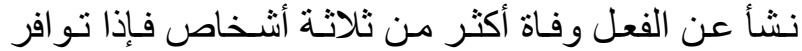
ظرف آخر من الظروف الواردة في الفقرة السابقة كانت العقوبة بالحبس مدة لا تقل عن سنة و لا تزيد على عشر التر فئرة

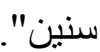

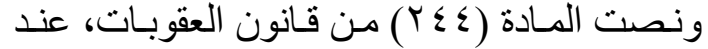

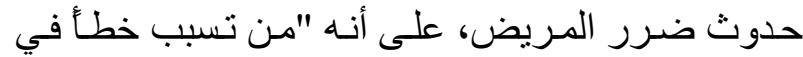

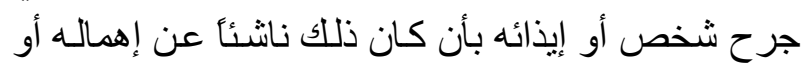

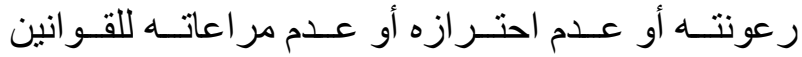

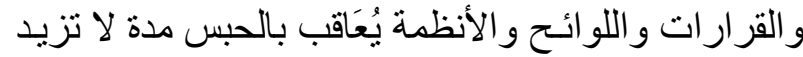

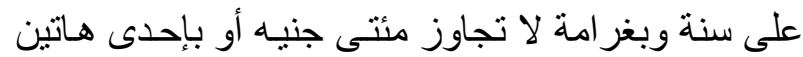

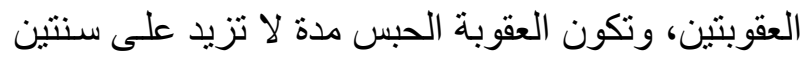
و غر امة لا تجاوز ثنلاثمائة جنية أو إحدى هاتين العقوبتين

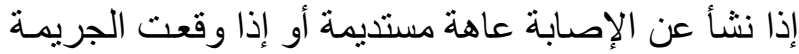

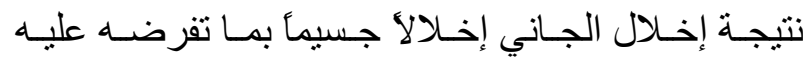
أصول وظيفته أو مهنته أو حرفته أو كان متعاطياً مسكراً

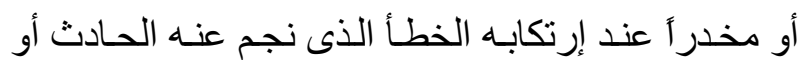

يكن لإر ادته دخل في حلوله ولا في قدرته منعها بطريقة أخرى".

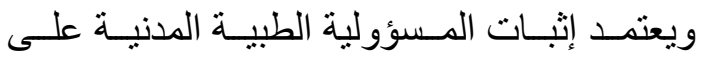

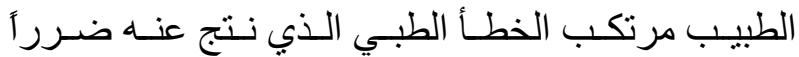

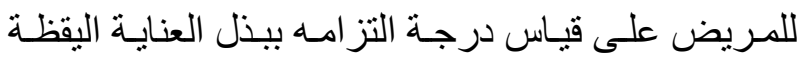

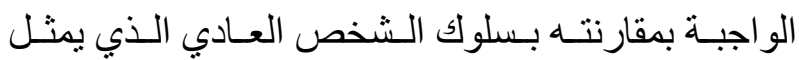

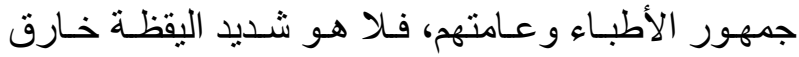
الـذكاء و لا هـو خامـل الهمـة محـدود الفطنـة، ومعيـار

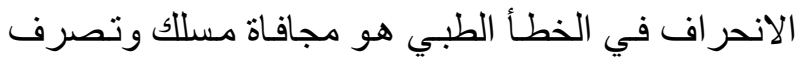

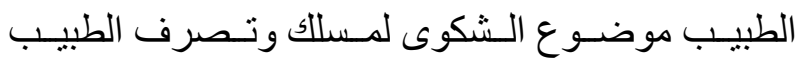
العـادي إذا وُجدـ في ظـروف ممانلـة، و إذا اتبـع الطبيـب

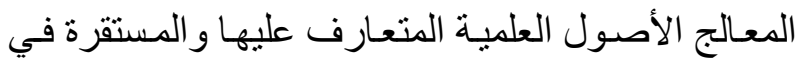

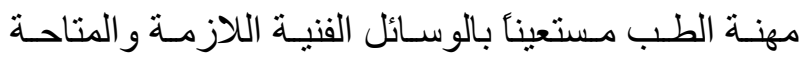
وبمن تستدعي حالة المريض الاستعانة بهم من الأطباء

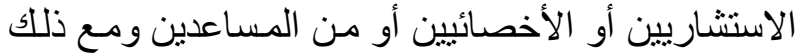

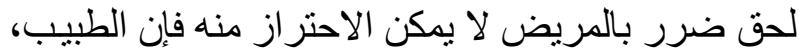

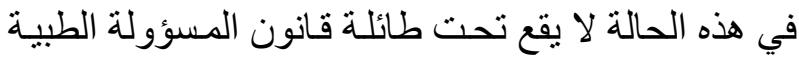
المدنية ولن يتعرض للمساءلة القانونية.

وقـــ أيـدت محكمــة الــنقض المـصرية قـضـاة

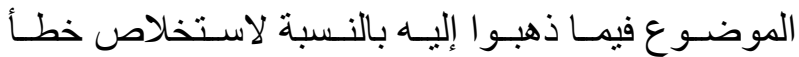
الطبيب من أمره بنقل مريضة من مستشفى جـامعي إلى إلى

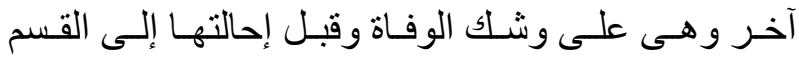
المختص مدـا أدى إلى التعجيـل بوفاتهـا وفي هذا الشتأن

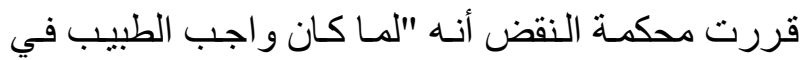
بذل العناية مناطه ما يقدمه طبيب يقظ من أوسط زملائهـ

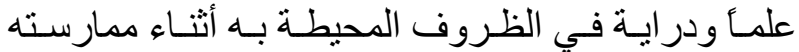

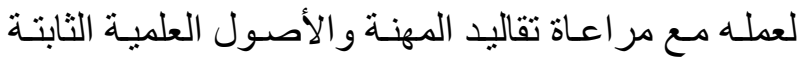

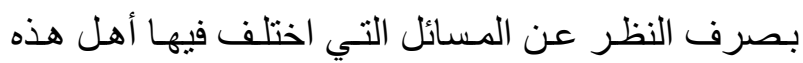

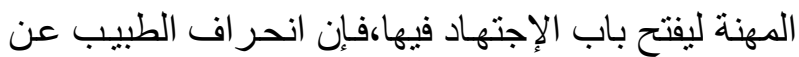

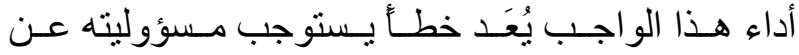

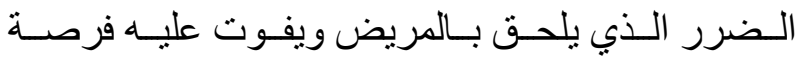

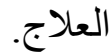


نكل وقت الحادث عن مساعدة من وقعت عليه الجريمـة

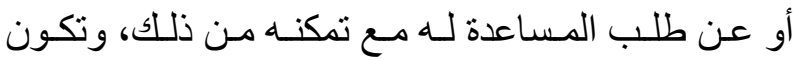
العقوبة الحبس إذا نشأ عن الجريمة إصابة أكثر من ثناثنة أشخاص، فاذا تو افر ظرف آخر من الظروف الواردة في الفقرة السابقة تكون العقوبـة الحبس مدة لا تقل عن سنة و لا تزيد على خمس سنين". 
د. فيصل الثورة (10 1 + Y): "الخطأ الطبي في القانون

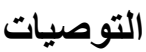

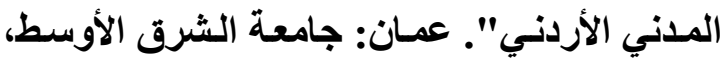

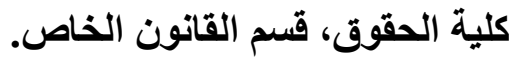

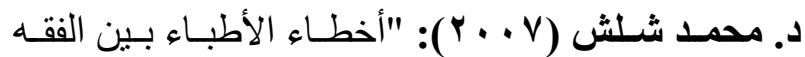

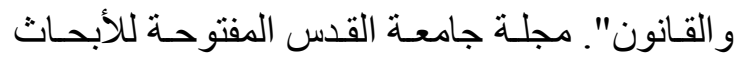

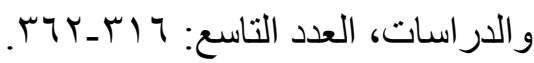
د. مسعودي حوريـة ومسعودين عبد السلام (0 1 + ب):

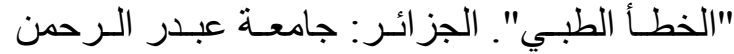
مبرة - بجايـة، كلية الحقوق والعلوم السياسية، قسم

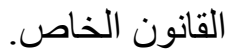

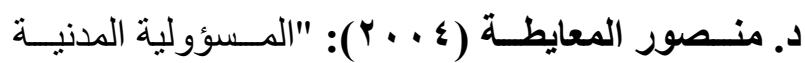

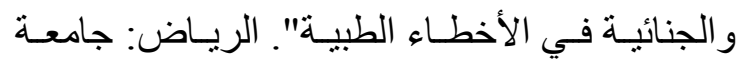

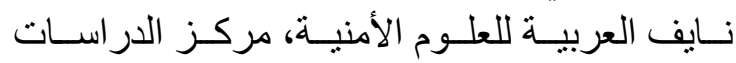

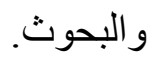

Helo, S. and Moulton, C.E. (2017): "Complications: acknowledging, managing and coping with human error". Transl. Androl. Urol., 6(4): 773-782.

Kim, Y.K. (2017): "Malpractice and complications". Journal of the Korean Association of Oral and Maxillofacial surgeons, 43(1): 1-2.

\section{Lehane,}

E.; Leahy-Warren,

P.; O'Riordan, C.; et al., (2018): "Evidence-based practice education for healthcare professions: an expert view". B.M.J. Evid. Based Med., 24(3): 103-108.

Vento, S.; Cainelli, F. and Vallone, A. (2018): "Defensive medicine: It is time to finally slow down an epidemic". 1 - إصدار قانون للمسؤولية الطبية يحتوي على معايير للأخطاء الطبية و العقوبات المقررة على كلي منها.

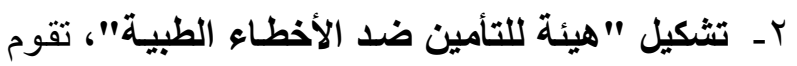

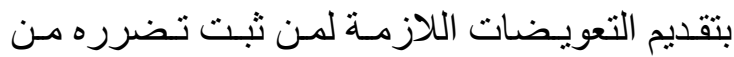
متلقي الخدمة الصحية بعد الوصـول إلى تسوية معسه

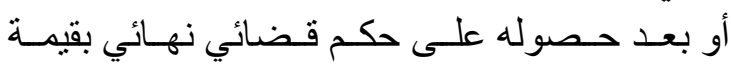

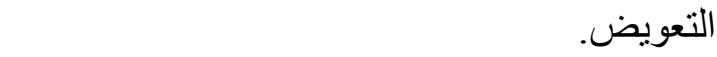
rـ تــــريس مقـرر "التعريـف بالمسـؤولية الأخلاقيـة

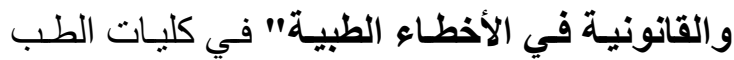
المصرية. ـ - وضـع آليـة لحـث الأطبـاء على التعليم والتـدريب

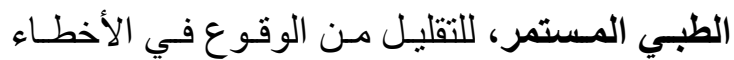
الطبية. 0ـ - إعـداد و إصــدار دليـل لسياسـات وإجـر اعت العــل يشمل وصف تفصيلي لمهام الممارسين الصحيين. د. صـالح العتيبـي (ع ا ـ Y): "الأخطـاء الطبيـة وتقدير

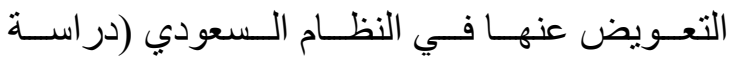
تطبيقيـة)". الريـاض: جامعـة نـايف العربيـة للعلـوم

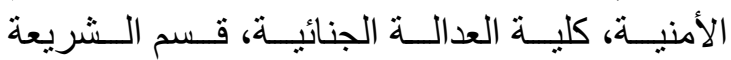
و القانون.

د. عبد الرحيم بن فاتح (0 10 • Y): "المسؤولية الجنائية

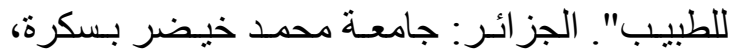
كلية الحقوق والعلوم السياسية، قسم الحقوق.

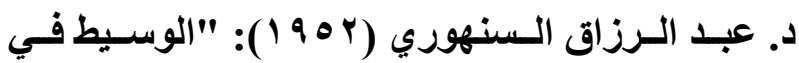

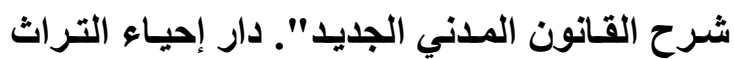
العربي، بيروت ـ لبنان.

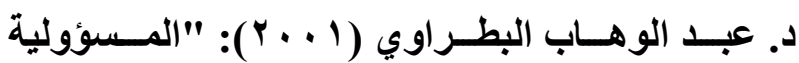

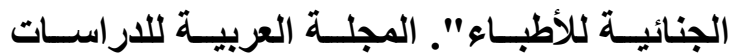

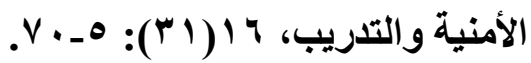
World J. Clin. Cases, 6 (11): 406-409. 